Winter 2006

\title{
Workers' Rights Provisions in Fast Track Authority, 1974-2007; An Historical Perspective and Current Analysis
}

Carol J. Pier

Human Rights Watch

Follow this and additional works at: https://www.repository.law.indiana.edu/ijgls

Part of the International Law Commons, and the Labor and Employment Law Commons

\section{Recommended Citation}

Pier, Carol J. (2006) "Workers' Rights Provisions in Fast Track Authority, 1974-2007; An Historical Perspective and Current Analysis," Indiana Journal of Global Legal Studies: Vol. 13 : Iss. 1 , Article 3. Available at: https://www.repository.law.indiana.edu/ijgls/vol13/iss1/3

This Symposium is brought to you for free and open access by the Law School Journals at Digital Repository @ Maurer Law. It has been accepted for inclusion in Indiana Journal of Global Legal Studies by an authorized editor of Digital Repository @ Maurer Law. For more information, please contact rvaughan@indiana.edu.

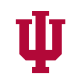

JEROME HALL LAW LIBRARY INDIANA UNIVERSITY Maurer School of Law
Bloomineton 


\title{
Workers' Rights Provisions in Fast Track Authority, 1974-2007: An Historical Perspective and Current Analysis
}

\author{
Carol Pier*
}

\begin{abstract}
This article examines the trajectory of workers' rights provisions in "fast track" authority legislation allowing the U.S. president to negotiate free trade agreements that Congress can only approve or reject, not amend. I begin my analysis with the Trade Act of 1974 and continue through the expiration of fast track authority in 1994. Against this backdrop, I critique the worker' rights negotiating objectives and priorities in the Bipartisan Trade Promotion Authority Act of 2002 (TPA). Relying on TPA's confused legislative history and basic rules of statutory interpretation, the article seeks to interpret TPA's workers' rights provisions. It concludes by examining the practical implications of TPA's workers' rights negotiating objectives and priorities, as currently applied, by assessing the workers' rights provisions in the trade accords concluded under TPA. Ultimately, I find that, despite pronouncements to the contrary, TPA is a step backward from the Trade Act of 1974, which instructed U.S. trade negotiators to ensure that "the global trading system, as governed by GATT, included an enforceable requirement that countries adhere to international fair labor standards."
\end{abstract}

\section{INTRODUCTION}

The Bipartisan Trade Promotion Authority Act of 2002 (TPA), included in the Trade Act of 2002, is the latest incarnation of "fast track" authority, first given to the U.S. president by Congress in the Trade Act of 1974. The primary purpose of fast track authority is to allow the president to negotiate free trade agreements that Congress can only approve or reject, not amend. Like its predecessors, however, TPA also establishes a substantive and procedural framework for the negotiation and subsequent congressional consideration of free trade accords. Its negotiating objectives and priorities address myriad trade-related is-

*The author is the labor rights and trade researcher for Human Rights Watch. The views expressed herein, however, are entirely her own. 
sues, including workers' rights, and directly impact trade agreement terms by guiding U.S. trade negotiators' treatment of these issues.

This article will examine the history of workers' rights provisions in fast track authority, beginning with the Trade Act of 1974 and continuing through the expiration of fast track authority on April 15, 1994. Against this historical backdrop, the article will analyze the workers' rights negotiating objectives and priorities in TPA. It will review the contentious congressional debate that surrounded TPA's labor rights provisions, identifying the key points of contention and discussing the disparate and often contradictory rhetoric used to characterize the workers' rights language. Relying on this confused legislative history, as well as the basic rules of statutory interpretation, the article will seek to interpret TPA's workers' rights provisions. It will conclude by examining the practical implication of TPA's labor rights objectives and priorities, as currently applied, by assessing the workers' rights provisions in the trade accords concluded under TPA.'

\section{History of Fast Track Workers' Rights Provisions}

From 1974 until its lapse in 1994, fast track was renewed roughly every four to five years: in the Trade Agreement Act of 1979; the Trade and Tariff Act of 1984; and the Omnibus Trade and Competitiveness Act of 1988 (Trade Act of 1988). After being extended by approximately one year in 1993, however, fast track expired, ${ }^{2}$ not to be renewed again until the Trade Act of 2002 created TPA, which has been extended through June 30, 2007. Although changes were made as each fast track authority was renewed, key changes to workers' rights provisions only occurred twice after the initial authorization of 1974-in the Trade Act of 1988 and in the Trade Act of 2002.

\section{A. Trade Act of 1974}

The overall and principal trade negotiating objectives set out in sections 104 through 107 of the 1974 fast track authority do not include guidance on linking workers' rights and trade. Instead, the Trade Act of 1974 addresses the labor-

1. The debate over linking workers' rights and trade, as well as the appropriate means for achieving such linkage in trade accords, are beyond the scope of this article.

2. The 1988 fast track applied to all qualifying agreements entered into before June 1, 1993. That date was extended through April 15, 1994, only with respect to the Uruguay Round trade agreements, discussed below. 19 U.S.C. § 2902(a)(1)(A), (e)(1) (2000). 
trade linkage in its section titled, "Steps to be Taken Toward GATT [General Agreement on Tariffs and Tradel Revision: Authorization of Appropriations for GATT." In that section, the Trade Act of 1974 orders that the president, "as soon as practicable, ... take such action as may be necessary to bring trade agreements heretofore entered into, and the application thereof, into conformity with principles promoting the development of an open, nondiscriminatory, and fair world economic system," including through "the adoption of international fair labor standards and of public petition and confrontation procedures in the GATT." 3

During the period that the Trade Act of 1974's workers' rights terms were in effect, from January 1975 until August 1988, the GATT was the only multilateral instrument governing international trade. ${ }^{4}$ Thus, revision of the GATT to fulfill the terms' objectives would have significantly impacted the global trading order, introducing enforceable workers' rights standards into all trading relationships among the GATT parties, numbering roughly eighty-two in January 1975 and nearly ninety-five by August 1988. ${ }^{5}$

The Senate Finance Committee Report of November 26, 1974, explains the rationale behind the Trade Act of 1974's workers' rights directive:

The Committee believes that international fair labor standards and procedures to enforce them should be established.... It believes... that additional steps are needed which would lead to the elimination of unfair labor conditions which substantially disrupt or distort international trade. The international trading community should seek to develop principles with respect to earnings, hours and conditions of employment of workers, and to adopt public petition and bargaining procedures. Efforts should be made to provide private persons the opportunity to appear before international economic organizations to present grievances. At the very

3. Trade Act of 1974, Pub. L. No. 93-618, § 121, 88 Stat. 1978, 1986 (1975).

4. The GATT entered into force in January 1948 and is the predecessor of the World Trade Organization, created in January 1995. Although the GATT's tariff concessions and trade rules have been revised through numerous negotiating rounds since 1948, the GATT, as revised, is still in effect today as one of the many trade instruments composing the legal framework of the World Trade Organization. See World Trade Org., Understanding the WTO 15-17 (3d ed. 2003).

5. See World Trade Org., The 128 Countries that had Signed GATT by 1994, http://www. wto.org/english/thewto_e/gattmem_e.htm. 
least, it would be appropriate to allow governments acting in their behalf to make representations concerning labor conditions. ${ }^{6}$

When read in light of its relevant legislative history, this directive not only affirms the linkage between workers' rights and global trade but suggests a rough structure for its practical implementation within the GATT - through a petition process, available at least to states if not also to private parties. By calling for enforceable universal labor standards within the GATT, the Trade Act of 1974 addresses one of the key issues characterizing the debate over the workers' rights and trade linkage: should countries be required to abide by internationally recognized workers' rights, or should they be required only to enforce their existing labor laws, leaving standard-setting to their discretion?

At the GATT's Tokyo Round-the seventh round of negotiations, which lasted from 1973 through 19797 - the United States arguably took a first step toward fulfilling the Trade Act of 1974's workers' rights directive when it proposed discussion of four "minimum international labor standards" regarding slave or forced labor, child labor, workplace health and safety, and discriminatory practices applied to exports. ${ }^{8}$ However, the U.S. proposal was ultimately rejected by other countries. As a result, the United States chose not to present a formal proposal on workers' rights, reportedly fearing negative repercussions for its other trade negotiating priorities. ${ }^{9}$ Nonetheless, in 1978, the Office of the U.S. Trade Representative created an interagency group to look further into the issue of addressing workers' rights during the Tokyo Round..$^{10}$ Almost one year later, the United States presented to the GATT Consultative Group of 18 (CG18) a proposal calling for minimum labor standards at least to be considered as part of the post-Tokyo Round work program." The CG-18 also failed to support this proposal, however, and it went no further. ${ }^{12}$

6. S. REP. No. 93-1298, at 7233-34 (1974).

7. WORLd Trade OrG., supra note 4, at 16.

8. Peter S. Watson, The Frameworkfor the New Trade Agenda, 25 Law \& PoL'y INT'L Bus. 1237, 1253 (1994).

9. Id. See also Elisabeth Cappuyns, Linking Labor Standards and Trade Sanctions: An Analysis of Their Current Relationship, 36 Colum. J. Transnat's L. 659, 665-66 (1998).

10. 140 Cong. Rec. E759 (daily ed. Apr. 21, 1994) (statement of Rep. Brown).

11. The CG-18 was an informal, high-level group of countries, generally chosen at the annual meeting of GATT parties, that discussed broad trade issues but possessed virtually no decisionmaking power.

12. Watson, supra note 8, at 1253. 
Approximately seven years later, in the fall of 1986, during the preparatory phase for the Uruguay Round-the eighth and final round of GATT negotiations-the United States once again pushed for the inclusion of workers' rights in the GATT negotiating agenda. ${ }^{13}$ Other countries again failed to support the proposal, however, and the issue was left off the September 1986 Punta del Este declaration officially launching the Uruguay Round. ${ }^{14}$ In July 1987, the United States tried once more, adopting an alternative approach by formally requesting a working party on the linkage between workers' rights and trade that was separate from the negotiating round. The United States proposed to address five basic international labor standards in the working party: freedom of association; freedom to organize and bargain collectively; freedom from forced or compulsory labor; a minimum age for the employment of children; and measures setting minimum standards in respect to conditions of work. ${ }^{15}$ The U.S. proposal was again rebuffed, however, and no working group was established. ${ }^{16}$

As a result, although U.S. trade negotiators took steps toward fulfilling the directive to "take such action as may be necessary" to secure the "adoption of international fair labor standards and of public petition and confrontation procedures in the GATT," the ultimate goal was never achieved.

Subsequent U.S. trade acts and fast track authorities have not called for the adoption of enforceable international workers' rights standards either in the GATT or in other free trade agreements. Although fast track legislation since 1974 has increasingly included more labor rights negotiating objectives and priorities, this greater quantity of provisions has been characterized by weaker and more ambiguous language. The simple and clear wording of the Trade Act of 1974's directive on workers' rights can thus be seen as the high-water mark in U.S. fast track legislation's treatment of the workers' rights and trade linkage.

\section{B. Omnibus Trade and Competitiveness Act of 1988}

After over thirteen years in force, the labor rights provisions in the Trade Act of 1974 were amended by the Omnibus Trade and Competitiveness Act of

13. R. Michael Gadbaw \& Michael T. Medwig, Multinational Enterprises and International Labor Standards: Which Way for Development and Jobs?, in Human Richts, Labor Rights and International Trade 141, 161 n.63 (Lance A. Compa \& Stephen F. Diamond eds., 1996); Watson, supra note 8 , at 1254 .

14. Watson, supra note 8 , at 1254.

15. Id.

16. Id.; Cappuyns, supra note 9, at 666; Gadbaw \& Medwig, supra note 13, at 152. 
1988. The 1988 legislation shifts treatment of workers' rights from the GATT appropriations section, where the Trade Act of 1974 includes its specific directive on the issue, to the principal trade negotiating objectives section. The Trade Act of 1988 includes among its principal negotiating objectives:

(A) to promote respect for worker rights;

(B) to secure a review of the relationship of worker rights to GATT articles, objectives, and related instruments with a view to ensuring that the benefits of the trading system are available to all workers; and

(C) to adopt, as a principle of the GATT, that the denial of worker rights should not be a means for a country or its industries to gain competitive advantage in international trade. ${ }^{17}$

The Act provides that trade agreements entered into under the Act must "make[] progress in meeting" the enumerated negotiating objectives. ${ }^{18}$

The Trade Act of 1988 does not further explain the objective to "promote respect for worker rights," leaving the definition of "promote" to the discretion of the U.S. president. Instead, as in the Trade Act of 1974, the workers' rights and trade linkage is largely addressed with reference to the GATT. The 1988 negotiating objectives, however, are weaker than the 1974 directive in several key aspects.

The 1988 legislation, for example, provides no guidance on how its workers' rights objectives should be fulfilled. It fails to elaborate on how to ensure "that the benefits of the trading system are available to all workers" or that the violation of workers' rights is not utilized to attract trade. In contrast, these principles underlie the workers' rights directive of the Trade Act of 1974, which explicitly dictates how they should be carried out: through the adoption of enforceable workers' rights provisions in the GATT. Similarly, the Trade Act of 1988 provides no reference point for understanding "worker rights," failing to identify whether "worker rights" should be defined by internationally recognized standards or countries' domestic laws. The Trade Act of 1974, however, explicitly called for the adoption of universally recognized standards.

17. 19 U.S.C. $\$ 2901(\mathrm{~b})(14)(2000)$.

18. 19 U.S.C. $\$ 2902$ (c)(3)(A) (2000). 
Nonetheless, guided by the Trade Act of 1988's negotiating objectives, U.S. trade negotiators again pushed to include workers' rights in the GATT's Uruguay Round, proposing in early 1994 that the following language be included in the political declaration of Marrakesh, where the final Uruguay Round Agreements creating the World Trade Organization (WTO) were signed: ${ }^{19}$

The Ministers recognize that the more open multilateral trading system resulting from the Uruguay Round should benefit workers around the world through the impact of increased trade on employment and income. They also expressed the view that trade gains should not come from the relaxation of social objectives and, in this connection, have agreed to undertake early consideration of the relationship between the trading system and internationally recognized labor standards. ${ }^{20}$

Like its predecessors, this proposal met significant opposition. Although the United States threatened to withhold its signature from the Uruguay Round Agreements unless they included an explicit commitment to address workers' rights in the WTO's future agenda, the United States did not follow through on this threat. ${ }^{21}$ Instead, the United States signed the accords, which contained no such commitment. As a result, as during the Tokyo Round, U.S. trade negotiators once again failed to fulfill the end goals articulated in the domestic legislation governing their international trade negotiations.

\section{TRADE Act of 2002}

The principal negotiating objectives on workers' rights established in the Trade Act of 1988 remained in effect until fast track authority expired in 1994. The U.S. president did not enjoy fast track authority again until TPA was approved as part of the Trade Act of 2002.

TPA shifts the focus of fast track's workers' rights provisions from making changes at the WTO level to the more general principle, included as a principal

19. Gadbaw \& Medwig, supra note 13, at 161 n.63.

20. Labor Standards Jeopardize Final Deal, Trade Wr. Rev. \& Recent Publications, Apr. 1, 1994, http://www.etext.org/Politics/Trade.News/Volume.3/tnb-03.013.

21. See id. 
negotiating objective in the Trade Act of 1988, of "promoting respect for workers' rights" through trade. TPA elaborates on this principle, setting out new and far more extensive workers' rights provisions than its predecessors. TPA includes workers' rights provisions in all three of its sections providing substantive guidance to U.S. trade negotiators: "Overall Trade Negotiating Objectives"; "Principal Trade Negotiating Objectives"; and "Promotion of Certain Priorities." "2- Yet, as discussed below, TPA nonetheless falls short of the workers' rights standard established in the Trade Act of 1974.

\section{A. TPA on Workers' Rights in the WTO}

In contrast to its two main predecessors, the Trade Act of 2002 addresses the linkage between workers' rights and the WTO only in its section on Promotion of Certain Priorities. TPA establishes as a priority to "seek greater cooperation between the WTO and the ILO [International Labour Organization]."23

TPA's priorities, however, are understood to enjoy second-class status among those TPA provisions providing substantive guidance to trade negotiators. For example, TPA establishes that an agreement "regarding tariff and nontariff barriers" may be entered into "only if such agreement makes progress in meeting" the Act's principal and overall negotiating objectives, failing to require any progress toward fulfilling TPA's articulated certain priorities. ${ }^{24}$ As Senator Phil Gramm (R-TX) noted, these priorities "do not carry the same weight as [TPA's overall and principal negotiating objectives]," discussed below, "[r]ather,

22. The international workers' rights priorities include: "seek greater cooperation between the WTO and the ILO"; "seek to establish consultative mechanisms among parties to trade agreements ... to promote respect for core labor standards ... and report to the Committee on Ways and Means of the House of Representatives and the Committee on Finance of the Senate on the content and operation of such mechanisms"; "direct the Secretary of Labor to consult with any country seeking a trade agreement with the United States concerning that country's labor laws and provide technical assistance to that country if needed"; "in connection with any trade negotiations entered into under this Act, submit to the Committee on Ways and Means of the House of Representatives and the Committee on Finance of the Senate a meaningful labor rights report of the country, or countries, with respect to which the President is negotiating"; and "with respect to any trade agreement which the President seeks to implement under trade authorities procedures, submit to the Congress a report describing the extent to which the country or countries that are parties to the agreement have in effect laws governing exploitative child labor." 19 U.S.C. $\S$ 3802(c)(1)-(2), (7)-(9) (Supp. II 2002).

23. 19 U.S.C. $\$ 3802(\mathrm{c})(1)$.

24. 19 U.S.C. $\S 3803($ b)(2) (Supp. II 2002). 
they are overall priorities that should be considered in general but by no means are items that should be the focus of a trade agreement." 25

Furthermore, TPA's priority addressing the trade and labor linkage in the WTO context is a significant step back wards from preceding fast track authorities' treatment of the issue. Rather than seeking to address workers' rights within the WTO institutional framework as the Trade Acts of 1974 and 1988 had done, TPA implicitly accepts WTO members' declaration at the 1996 Singapore Ministerial Conference that the ILO, rather than the WTO, "is the competent body to set and deal with these [internationally recognized labor] standards." ${ }^{26}$ Departing from the Trade Act of 1988, TPA does not call for a review of the relationship between labor rights and the WTO nor seek WTO adoption of the principle that denial of workers' rights is an illegitimate means for attracting trade. Similarly, unlike the Trade Act of 1974, TPA does not seek enforceable universal labor standards in the WTO. To the contrary, as discussed below, there is significant debate over whether TPA would even permit U.S. trade negotiators to pursue that 1974 goal either in the WTO or in other bilateral, multilateral, or regional trade accords.

TPA's sole priority addressing workers' rights in the WTO is nonetheless reminiscent of a similar provision found in the Uruguay Round Agreements Act, enacted in December 1994 to implement the agreements creating the WTO. The Uruguay Round Agreements Act directs the president to "seek the establishment ... in the WTO, of a working party to examine the relationship of internationally recognized worker rights ... to the articles, objectives, and related instruments of the ... WTO"27 and sets forth four objectives for the working party:

(1) explore the linkage between international trade and internationally recognized worker rights ... taking into account differences in the level of development among countries; (2) examine the effects on international trade of the systematic denial of such rights; (3) consider ways to address such effects; and (4) develop

25. S. Rep. No. 107-139, at 41-42 (2002).

26. World Trade Org., Singapore Ministerial Declaration of 13 December 1996, WT/MIN(96)/ DEC/W, 36 I.L.M. 218 (1997), available at http://www.wto.org/english/thewto_e/minist_el min96_e/wtodec_e.htm.

27. 19 U.S.C. $\$ 3551$ (a) (2000). 
methods to coordinate the work program of the working party

with the International Labor Organization. ${ }^{28}$

TPA, however, only includes the last of these four objectives as a negotiating priority.

Thus, TPA not only falls short of the standard set by the Trade Acts of 1974 and 1988 for addressing the workers' rights and trade linkage in the WTO context but also that of the Uruguay Round Agreements Act of 1994. Instead, TPA follows the approach, adopted by the WTO Singapore Ministerial Conference, of relegating workers' rights to the exclusive jurisdiction of the ILO.

Nonetheless, the debate over the practical implications of TPA's workers' rights provisions has not primarily focused on the treatment of workers' rights in the WTO. No subsequent WTO ministerial conferences have made any meaningful progress toward altering the position adopted on workers' rights at the 1996 WTO Singapore Ministerial Conference, and the issue has largely been sidelined by members struggling to reach consensus on other trade-related issues. With workers' rights to a great extent marginalized at the WTO, disagreement over TPA's workers' rights provisions has, instead, focused primarily on whether U.S. negotiators of other multilateral, regional, or bilateral free trade agreements can, as the Trade Act of 1974 directed over twenty years ago, seek the adoption of enforceable universal labor standards. This highly contentious debate revolves around the interpretation and application of TPA's overall and principal negotiating objectives.

\section{B. TPA's Overall and Principal Negotiating Objectives}

TPA establishes a number of overall and principal negotiating objectives on workers' rights that U.S. negotiators are directed to pursue in free trade negotiations.

TPA includes among its overall negotiating objectives: "to promote respect for worker rights... and an understanding of the relationship between trade and worker rights"; $; 9$ "to seek provisions in trade agreements under which parties to those agreements strive to ensure that they do not weaken or reduce the protections afforded in domestic...labor laws as an encouragement for

28. 19 U.S.C. $\$ 3551(\mathrm{a})-(\mathrm{b})(2000)$.

29. 19 U.S.C. $\S 3802(a)(6)$ (Supp. II 2002). 
trade"; 30 and "to promote universal ratification and full compliance with ILO convention No. 182 Concerning the Prohibition and Immediate Action for the Elimination of the Worst Forms of Child Labor." ${ }^{31}$

TPA's key principal negotiating objectives on labor include: "to ensure that a party to a trade agreement with the United States does not fail to effectively enforce its ... labor laws, through a sustained or recurring course of action or inaction, in a manner affecting trade between the United States and that party"; ${ }^{32}$ to "strengthen the capacity of United States trading partners to promote respect for core labor standards", ${ }^{33}$ and "to seek commitments by parties to trade agreements to vigorously enforce their own laws prohibiting the worst forms of child labor." 34

TPA's principal negotiating objectives on workers' rights, however, also contain important qualifying language, set forth as principal negotiating objective (11)(B):

$[T]$ o recognize that parties to a trade agreement retain the right to exercise discretion with respect to investigatory, prosecutorial, regulatory, and compliance matters and to make decisions regarding the allocation of resources to enforcement with respect to other labor ... matters determined to have higher priorities, and to recognize that a country is effectively enforcing its laws if a course of action or inaction reflects a reasonable exercise of such discretion, or results from a bona fide decision regarding the allocation of resources, and no retaliation may be authorized based on

30. 19 U.S.C. $\S 3802(a)(7)$.

31. 19 U.S.C. $\$ 3802(a)(9)$.

32. 19 U.S.C. $\$ 3802(\mathrm{~b})(11)(\mathrm{A})$

33. 19 U.S.C. $\$ 3802$ (b)(11)(C). TPA defines "core labor standards" as: "the right of association"; "the right to organize and bargain collectively"; "a prohibition on the use of any form of forced or compulsory labor"; "a minimum age for the employment of children"; and "acceptable conditions of work with respect to minimum wages, hours of work, and occupational safety and health." 19 U.S.C. $\S 3813$ (6) (Supp. II 2002). This definition, however, excludes "the elimination of discrimination in respect of employment and occupation," which the ILO has identified as one of the four fundamental workers' rights, which also include: "freedom of association and the effective recognition of the right to collective bargaining"; "the elimination of all forms of forced or compulsory labour"; and "the effective abolition of child labour." See ILO Declaration on Fundamental Principles and Rights at Work, art. 2, June 18, 1998, 37 I.L.M. 1233, 1237 (1988).

34. 19 U.S.C. $\$ 3802(b)(17)$. 
the exercise of these rights or the right to establish domestic labor standards.... ${ }^{35}$

The important and fundamental distinction between these overall and principal negotiating objectives is established in principal negotiating objective $(12)(G)$ on dispute settlement and enforcement, which sets out as an objective: "to seek provisions that treat United States principal negotiating objectives equally with respect to" access to dispute settlement mechanisms and the procedures and remedies offered by those mechanisms. ${ }^{36}$ As a result, under TPA, only those trade agreement provisions that fulfill the principal negotiating objectives must be enforceable, giving rise to dispute settlement proceedings and possible fines or sanctions if violated. ${ }^{37}$ Those trade agreement provisions that, to the contrary, fulfill either the overall negotiating objectives or certain articulated priorities need not be enforceable through dispute settlement procedures and remedies equal to other accord provisions and, instead, may be merely hortatory and aspirational.

The qualifying language of principal negotiating objective (11)(B) and the distinction between overall and principal negotiating objectives clarified in principal negotiating objective $(12)(G)$ are at the center of the debate over TPA's workers' rights provisions: can TPA's overall negotiating objectives give rise to enforceable workers' rights protections in free trade accords or, to the contrary, does TPA preclude this possibility?

\section{TPA and the U.S.-Jordan Free Trade Agreement}

\section{The Jordan Standard on Workers' Rights}

The debate over the interpretation and application of TPA's workers' rights provisions has largely unfolded against the backdrop of the U.S.-Jordan Free Trade Agreement (U.S.-Jordan FTA), signed by the U.S. president in October 2000 and entered into force in December 2001. The U.S.-Jordan FTA is seen by many as the high-water mark for the inclusion of strong workers' rights provisions in free trade agreements. The question at the heart of the debate can be reframed with reference to the U.S.-Jordan FTA: does TPA permit U.S.

35. 19 U.S.C. $\S 3802(\mathrm{~b})(11)$ (B).

36. 19 U.S.C. $\$ 3802(\mathrm{~b})(12)(\mathrm{G})$ (emphasis added).

37. See id. 
negotiators to negotiate free trade agreements that meet the workers' rights standard of the U.S.-Jordan FTA (Jordan standard)?

To answer this fundamental question, it is imperative to understand not only the legal text of the U.S.-Jordan FTA workers' rights provisions, but also the disagreement regarding that accord's interpretation.

The U.S.-Jordan FTA contains four key workers' rights provisions, as well as a fifth that acknowledges that "cooperation between [the parties] provides enhanced opportunities to improve labor standards." ${ }^{38}$ The four key provisions require parties to: "strive to ensure" that the labor principles of the ILO Declaration on Fundamental Principles and Rights at Work and the internationally recognized labor rights set forth in the accord are recognized and protected by national law; "strive to ensure" that they do not waive or otherwise derogate from, or offer to waive or otherwise derogate from, national labor laws as an encouragement for trade; "strive to ensure" that their laws provide for labor standards consistent with the internationally recognized labor rights set forth in the accord and "strive to" improve those standards in that light; and not fail to effectively enforce their labor laws through a sustained or recurring course of action or inaction in a manner affecting trade between the parties. ${ }^{39}$

These requirements, however, also have caveats. The requirement that parties strive to ensure that their laws meet international standards and to improve those laws is qualified by the explicit recognition of each party's parallel right "to

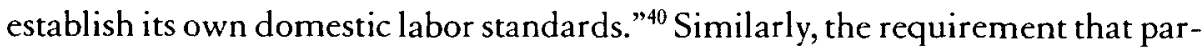
ties effectively enforce their labor laws is qualified by the clarification that each party also "retains the right to exercise discretion with respect to investigatory, prosecutorial, regulatory, and compliance matters and to make decisions regarding the allocation of resources to enforcement with respect to other labor matters determined to have higher priorities." Accordingly, "the Parties understand that a Party is in compliance with [the agreement] where a course of action or inaction reflects a reasonable exercise of such discretion, or results from a bona fide decision regarding the allocation of resources." ${ }^{41}$

38. Agreement on the Establishment of a Free Trade Area, U.S.-Jordan, art. 6(5), Oct. 24, 2000, 41 I.L.M. 63, 70 (entered into force Dec. 17, 2001) [hereinafter U.S.-Jordan FTA].

39. Id. art. 6(1)-(4), 41 I.L.M. at 70. The workers' rights identified by the U.S.-Jordan FTA as "internationally recognized labor rights" are the same rights that TPA lists as "core labor standards." The U.S.-Jordan FTA also defines "labor laws" for the purposes of the accord as those statutes and regulations directly related to those rights. Id. art. 6(6), 41 I.L.M. at 71. See supra note 34.

40. U.S.-Jordan FTA, supra note 38, art. 6(3), 41 I.L.M. at 70.

41. Id. art. 6(4)(b), 41 I.L.M. at 70. 
These caveats, combined with the "strive to" qualifier preceding three of the four key workers' rights provisions, have complicated efforts to arrive upon one accepted interpretation of the Jordan standard on workers' rights. For example, during the congressional debate over TPA, Senator Charles Grassley (R-IA), chairman of the Senate Finance Committee, commented:

[N]o one really knows what the "Jordan Standard" is. In fact, when we held a hearing on the Jordan Free Trade Agreement on March 20, 2001 in the Senate Finance Committee, one of the most controversial issues raised was what the labor ... provisions of the Jordan Free Trade Agreement actually mean.... Ambassador Michael Smith, former Deputy United States Trade Representative and the first American Ambassador to the General Agreement on Tariffs and Trade, testified that "Articles 5 and 6 [of the Jordan FTA] as written are largely fluff, open to widely differing, even if plausible, interpretations and, as such, causes for possible unfortunate differences between Jordan and the United States in the years ahead as the agreement is implemented." 42

Despite the confusion and discord, the U.S.-Jordan FTA workers' rights provisions do, in fact, provide a clear standard on workers' rights, characterized by three key components. The first component sets the U.S.-Jordan FTA apart from all other free trade accords: all provisions of the U.S.-Jordan FTA, be they labor, environmental, or commercial, if violated, are subject to the same dispute settlement mechanism and remedies. ${ }^{43}$ As noted in the legislative history of the

42. 148 Conc. Rec. S9107, S9107-08 (daily ed. Sept. 24, 2002) (statement of Sen. Grassley).

43. In July 2001, the United States and Jordan signed side letters on labor and environment in which they stated that they "would not expect or intend to apply the Agreement's dispute settlement procedures to secure its rights under the Agreement in a manner that results in blocking trade." They further added that they consider "that appropriate measures for resolving any differences that may arise regarding the Agreement would be bilateral consultations and other procedures, particularly alternative mechanisms, that will help to secure compliance without recourse to traditional trade sanctions." Letter from Robert B. Zoellick, United States Trade Representative, to Marwan Muasher, Ambassador of the Hashemite Kingdom of Jordan to the United States of America (July 23, 2001), available at http://www.tcc.mac.doc.gov/cgi-bin/doit.cgi?204:67:298771046:313; Letter from Marwan Muasher, Ambassador of the Hashemite Kingdom of Jordan to the United States of America, to Robert B. Zoellick, United States Trade Representative (July 23, 2001), available at http:/www.tcc.mac.doc.gov/cgi-bin/doit.cgi:204:67:298771046:312. These letters, however, are an expression of executive will and cannot override the legal text of the ratified accord. 
U.S.-Jordan Free Trade Area Implementation Act, which gives effect to the U.S.-Jordan FTA in the United States, "the U.S.-Jordan free trade agreement accords the labor and environmental provisions equal status to all other provisions in the agreement, including with regard to dispute settlement and enforcement." ${ }^{44}$ The second component is also relatively straightforward: with the caveat that parties retain discretion over enforcement and resource allocation decisions, the U.S.-Jordan FTA requires parties to effectively enforce their labor laws in those areas affecting trade between them. It is the third component, however, that lies at the heart of the controversy over the Jordan standard, establishing that while parties retain the right to set their own domestic labor standards, they must strive to ensure that their labor laws meet and protect international standards, strive to improve those laws in that light, and strive to ensure that they do not weaken or offer to weaken those laws to attract trade.

The "strive to" language is the primary source of confusion over the Jordan standard's third component. Some argue that requiring a country to strive to fulfill an obligation is such a soft directive that, at the end of the day, it is unenforceable. For example, in March 2004, the editorial page of the Washington Post observed, "Jordan merely promises to 'strive to ensure' compliance, a term too vague to provide for a strong right of action." ${ }^{45}$ Similarly, in the House of Representatives Committee on Ways and Means Report on the U.S.-Jordan Free Trade Area Implementation Act, five representatives wrote, "Much of the... labor language does not establish binding obligations. The parties are, for example, committed only to 'strive to ensure' that their domestic ... labor laws will not be relaxed." ${ }^{46}$

"Strive to" qualifying language, however, does not render the directives following it unenforceable. Though it weakens those requirements, they nonetheless contain binding terms. The United Nations Committee on Economic, Social and Cultural Rights' (CESCR) comments on similar language contained in the International Covenant on Economic, Social and Cultural Rights (ICESCR) are instructive. The ICESCR requires each state party "to take steps, ... to the maximum of its available resources, with a view to achieving progressively the full realization of the rights recognized in the present Covenant by all appropriate

44. H.R. Rep. No. 107-176, pt. 1, at 18 (2001).

45. Editorial, Trade and the Campaign, Wash. Post, Mar. 15, 2004, at A24.

46. H.R. Rep. No. 107-176, pt. 1, at 22 (2001) (“Additional Views” of Reps. Doggett, Matsui, McDermott, Lewis, and Thurman). 
means." ${ }^{\text {+7 }}$ Although the qualifying language of the U.S.-Jordan FTA and the ICESCR differs slightly, the implications are similar, as reflected in the CESCR comment that "even where the available resources are demonstrably inadequate, the obligation remains for a State party to strive to ensure the widest possible enjoyment of the relevant rights under the prevailing circumstances." ${ }^{28}$

Explaining the significance of requiring states parties to take steps or strive toward an ultimate goal, the CESCR explains that:

[W] hile the full realization of the relevant rights may be achieved progressively, steps toward that goal must be taken within a reasonably short time after the Covenant's entry into force for the States concerned. Such steps should be deliberate, concrete and targeted as clearly as possible towards meeting the obligations recognized in the Covenant. ${ }^{49}$

The CESCR further notes:

[T] he fact that realization over time, or in other words progressively, is foreseen under the Covenant should not be misinterpreted as depriving the obligation of all meaningful content.... [T] he phrase must be read in the light of the overall objective... of the Covenant which is to establish clear obligations for States parties in respect of the full realization of the rights in question. It ... imposes an obligation to move as expeditiously and effectively as possible towards that goal. Moreover, any deliberately retrogressive measures in that regard would require the most careful consideration and would need to be fully justified. ${ }^{50}$

If a similar analysis is applied to the third component of the Jordan standard, three key elements of that component emerge. First, the parties must take

47. International Covenant on Economic, Social and Cultural Rights art. 2(1), Dec. 16, 1966, S. Exec. Doc. D, $95-2$ (1978), 993 U.N.T.S. 3.

48. U.N. Econ. \& Soc. Council, Comm. on Econ., Soc. and Cultural Rights, General Comment 3: The Nature of States Parties Obligations If 11, U.N. Doc. E/1991/23 (Dec. 14, 1990) (emphasis added).

49. Id. I 2 .

50. Id. ๆ 9. 
"deliberate, concrete, and targeted" steps, within a reasonable amount of time after the U.S.-Jordan FTA enters into force, to ensure that their labor laws meet and protect international standards, to improve those laws, and to ensure that they do not weaken or offer to weaken those laws to attract trade. Second, the parties must move as "expeditiously and effectively" as possible toward this goal. Third, to remain in compliance with the accord, the parties must fully justify any measures moving away from that goal, such as amending laws to ban unions in free trade zones or waiving the minimum age of employment in the agroexport sector to encourage investment.

Following this line of reasoning, while the U.S.-Jordan FTA's qualifying "strive to" language makes enforcement of the requirements that follow more complicated and subjective, the requirements are nonetheless very much enforceable. This interpretation is supported by the September 2001 remarks of Senator Gramm during the Senate floor debate over the U.S.-Jordan Free Trade Area Implementation Act, during which he repeatedly expressed his displeasure with the accord's workers' rights provisions, warning:

Under this bill, we agree with Jordan that we will not take any actions with regard to our labor... laws that would advantage us in our trading with Jordan.....

Now, granted the Clinton administration puts nice boilerplate language that says to Jordan, you make your own laws; and it says to the United States, you make your own laws. But it also says, if those laws are judged to improve your competitiveness as a result of a reduction in your level of ... protection, then there can be reprisals.

.. [W] could find ourselves in a situation where a change in a labor... law was judged by an international decisionmaking body or dispute resolution mechanism to benefit us in trade.... But by judging it in those terms, we could literally have tariffs imposed on any American product sold on the world market. ${ }^{51}$

51. 147 Conc. Rec. S9679, S9686-92 (daily ed. Sept. 24, 2001) (statement of Sen. Gramm). 


\section{TPA's Failure to Incorporate the Jordan Standard}

TPA's overall and principal negotiating objectives on workers' rights contain language very similar to the U.S.-Jordan FTA's workers' rights provisions, which led certain members of Congress during the heated TPA debate to erroneously characterize TPA as meeting the Jordan standard.

For example, Representatives William J. Jefferson (D-LA) and John Tanner (D-TN) stated that TPA “includes a substantive, enforceable standard on labor

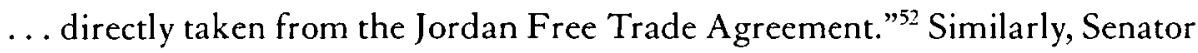
Max Baucus (D-MT) explained to the Democratic Leadership Council:

[F]ast track language incorporates all of the elements of the Jordan Agreement. ... [T] hose who criticize the fast track bill as not meeting the Jordan standard are simply wrong. . . [I] t makes Jordan the model for new negotiations. ... Jordan constitutes a practical floor for future agreements. ${ }^{53}$

Additionally, Senator Baucus told an audience at the Institute for International Economics:

The Senate bill expressly directs U.S. negotiators to pursue labor rights ... provisions in new agreements that ... fully reflect the standard set forth in the U.S.-Jordan FTA. ${ }^{54}$

In the Senate debate over the conference report on the Trade Act of 2002, Senator Baucus reiterated that view with respect to TPA's workers' rights provisions:

[T]his bill adopts the standards set forth in the United StatesJordan Free Trade Agreement; that is, as a floor. No standards in future trade agreements can go below the floor set in the United

52. H.R. Rep. No. 107-249, pt. 1, at 81 (2001) (“Additional Views” of Reps. Jefferson \& Tanner). At the same time, however, they also noted that TPA "does not take steps to impose [labor] standards on developing countries," and lamented that "[s]ome of our colleagues advocate for the imposition of ILO standards on developing countries ... a position that has no chance of succeeding domestically or internationally." Id.

53. Sen. Max Baucus, Statement to the Democrat Leadership Council (Feb. 12, 2001).

54. Sen. Max Baucus, Statement before the Institute for International Economics (Feb. 26, 2002). 
States-Jordan Free Trade Agreement, which is a pretty high floor, but certainly agreements can be higher.

The conference bill's fast-track provisions fully adopt the Jordan provisions, and the bill makes it clear that Jordan is the model for every free-trade agreement we negotiate; that is, the bottom floor is Jordan. ${ }^{55}$

Nonetheless, TPA falls short of including the three components of the Jordan standard on workers' rights articulated above, instead containing only the second.

Only if TPA articulated all four of the U.S.-Jordan FTA's key workers' rights provisions among its principal negotiating objectives-all of which must give rise to equally enforceable trade accord provisions-would the legislation arguably incorporate the Jordan standard. TPA, however, includes only one of the four as a principal negotiating objective: that countries not fail to effectively enforce their labor laws in a manner affecting trade between them. The requirement that countries strive to ensure that they do not weaken or reduce domestic labor laws to encourage trade is contained among TPA's overall negotiating objectives, which in contrast to principal negotiating objectives, may give rise to unenforceable, hortatory trade accord provisions. The U.S.-Jordan FTA language demanding that parties strive to ensure that their labor laws meet international standards, to improve them in that light, and not to offer to weaken or reduce those laws to attract trade is omitted entirely from TPA.

Thus, as Senator Christopher Dodd (D-CT) noted, unlike the U.S.-Jordan FTA, which "actually includes provisions safeguarding minimum labor standards in the main text of the agreement," we trade ... to strive to meet the standards of the ILO. This means our trading partners may fail to prohibit child labor or forced labor if no such domestic laws exist." ${ }^{57}$ Representatives Charles B. Rangel (D-NY), Michael R. McNulty (DNY), Robert T. Matsui (D-CA), Sander Levin (D-MI), William J. Coyne (D-PA), and Xavier Becerra (D-CA) similarly observed that, in contrast to the U.S.-Jordan FTA, TPA "would provide only that a country enforce its own laws whatever they may be. There is only rhetoric and no requirement that a country's law include

55. 148 Conc. Rec. S7768 (daily ed. Aug. 1, 2002) (statement of Sen. Baucus).

56. 148 Cong. Rec. S4824, S4825 (daily ed. May 23, 2002) (statement of Sen. Dodd).

57. Id. 
any of the five core labor standards—bans on child labor, discrimination, and slave labor, and the rights to associate and to bargain collectively." 58

As a result, a number of lawmakers have sought to highlight that despite occasional statements to the contrary, TPA fails to incorporate the Jordan standard. Senator Dodd observed:

[T] he fast track bill that passed the House and the one that just passed this body does not include Jordan standards.... An amendment that $I$ offered requiring new fast-track authority to be in parity with the Jordan standards was voted down.... The managers of this bill have mistakenly been saying that the bill follows the labor conditions contained in the Jordan agreement. ${ }^{59}$

Agreeing with Senator Dodd, Senator Charles Grassley (R-IA) noted:

I am deeply concerned that some... Members of Congress are pushing the Administration to adhere to a highly controversial and vague "Jordan Standard"... that is not clearly reflected in the Trade Promotion Authority negotiating objectives. While the labor ... and dispute settlement negotiating objectives in the Bipartisan Trade Promotion Authority Act are loosely based on provisions found in the Jordan Free Trade Agreement, there is clearly a distinction between the two. In implementing the will of Congress as embodied in the Trade Promotion Authority Act, it is critically important for the administration to keep this distinction in mind. ${ }^{60}$

Senator Gramm also concurred, explaining:

In general, the Jordan Free Trade Agreement (FTA) must not be considered as a new template for future trade bills in general and

58. H.R. Rep. No. 107-249, pt. 1, at 54 (2001) (“Dissenting Views” of Reps. Rangel, McNulty, Matsui, Levin, Coyne, and Becerra). The "core labor standards" to which the representatives refer are the fundamental workers' rights identified by the ILO Declaration on Fundamental Principles and Rights at Work. See ILO Declaration on Fundamental Principles and Rights at Work, supra note 34 .

59. 148 Cong. Rec. S4824, S4825-26 (daily ed. May 23, 2002) (statement of Sen. Dodd).

60. 148 Cong. Rec. S9107 (daily ed. Sept. 24, 2002) (statement of Sen. Grassley). 
this bill in particular.... While some elements of the Jordan FTA are present in this bill, it certainly does not embody a "Jordan standard" of any kind. ${ }^{61}$

\section{Does TPA Allow Accords to Meet the Jordan Standard?}

Although TPA does not require that free trade accords meet the Jordan standard on workers' rights, a more complex question is whether TPA at least permits them to do so. More specifically, the question is whether TPA allows the negotiation of free trade accords in which all four of the U.S.-Jordan FTA's key workers' rights provisions are binding and enforceable: the one included in TPA as a principal negotiating objective, the one included as an overall negotiating objective, and the ones excluded from TPA entirely.

The answer, as implied above, turns on the interpretation of language in two key TPA provisions: principal negotiating objective (12) to seek provisions that treat all "principal" negotiating objectives equally with respect to dispute settlement mechanisms; and the qualifying language of principal negotiating objective (11)(B), added by Senator Gramm and known as the "Gramm language," that "no retaliation may be authorized based on the exercise" of parties" rights, set forth in the immediately preceding text, to "exercise discretion with respect to investigatory, prosecutorial, regulatory, and compliance matters and to make decisions regarding the allocation of resources to enforcement with respect to other labor ... matters determined to have higher priorities" and their right "to establish domestic labor standards." "63

Although principal negotiating objective (12) requires that all free trade accord provisions giving effect to principal negotiating objectives be "equally" enforceable with equally available equivalent dispute settlement procedures and remedies, ${ }^{64}$ it is silent with respect to overall negotiating objectives. It fails to require such enforcement parity for trade accord provisions fulfilling these objectives but also fails to prohibit parity. Thus, principal negotiating objective (12) leaves open the option of enforceable trade agreement provisions based on TPA's overall negotiating objectives or on objectives not even articulated in the legislation.

61. S. REP. No. 107-139, at 64 (2002) (“Additional Views" of Sen. Gramm).

62. 148 Cong. Rec. S4826 (daily ed. May 23, 2002) (statement of Sen. Dodd).

63. 19 U.S.C. $\S 3802$ (b)(11)(B) (Supp. II 2002).

64. See 19 U.S.C. $\S 3802(b)(12)(G)$. 
The Gramm language, however, explicitly bans retaliation against countries for exercising certain explicitly articulated rights, which can be divided into two categories: the right to exercise discretion regarding labor law enforcement and the right to establish domestic labor standards. To determine whether the Gramm language prevents free trade accords negotiated under TPA from meeting the Jordan standard, the scope of this ban as applied to these rights must be defined.

Like the U.S.-Jordan FTA, TPA provides not only that countries retain the right to exercise discretion with respect to labor law application decisions, including resource allocation for enforcement, but that any "reasonable exercise of such discretion," or a "bona fide decision" regarding resource allocation, shall not be considered a free trade accord violation. ${ }^{65}$ Therefore, trade agreement parties shall face no punitive consequences as a result of the "reasonable exercise" of this right. Thus, when it explicitly asserts that "no retaliation may be authorized based on the exercise" of this right, the Gramm language is merely redundant. As Senator Baucus similarly observed, the Gramm language serves only:

to clarify the language that precedes it in subparagraph (B). That is, in negotiating provisions on trade and labor..., the United States should make clear that a country is effectively enforcing its laws if a course of action or inaction is the result of a reasonable exercise of discretion or a bona fide decision regarding the allocation of resources, and, as such, the country cannot be subject to retaliation on the basis of that course of action or inaction alone. ${ }^{66}$

Furthermore, to interpret the Gramm language more broadly to ban all retaliation related to domestic labor law enforcement would render TPA internally contradictory. Specifically, the Gramm language would make it impossible to negotiate a free trade accord provision, enforceable through equivalent dispute settlement mechanisms and remedies, that fulfilled TPA's principal negotiating objective to ensure that countries effectively apply their domestic labor laws. ${ }^{67}$ Yet TPA instructs U.S. trade negotiators to do just that.

65. 19 U.S.C. $\S 3802$ (b)(11)(B); see U.S.-Jordan FTA, supra note 38, art. 6(4)(b), 41 I.L.M. at 70.

66. S. Rep. No. 107-139, at 30 (2002).

67. Internal contradiction should be avoided when interpreting statutes. See 2A Norman J. Singer, Statutes and Statutory Construction 500 (6th ed. 2000). 
Thus, the first part of the Gramm language barring retaliation merely reiterates provisions already set forth in TPA, as well as the U.S.-Jordan FTA, and it presents no obstacle to the fulfillment of the Jordan standard on workers' rights in free trade accords negotiating under TPA.

Nonetheless, the second part of the Gramm language-that "no retaliation may be authorized based on the exercise of ... the right to establish domestic labor standards"-raises more difficult issues. Specifically, does this limitation preclude the negotiation of enforceable free trade accord provisions that, like in the U.S.-Jordan FTA, prohibit countries from weakening or derogating from their domestic labor laws or offering to do so to attract trade, or that require that countries' domestic laws meet international standards and that they improve them in that light?

In this regard, Senator Dodd noted:

The few Jordan standards that are in the bill have been made meaningless by the rejection of Senator Lieberman's amendment which would have deleted four lines from the bill that were added by Senator Gramm of Texas. The Gramm language states that a party has the right to establish its own domestic labor standards ... regardless of how these domestic laws may deviate from accepted international norms in these areas.... Other countries can weaken their labor... laws to gain a competitive advantage, and we will have no recourse against such actions. ${ }^{68}$

But does the Gramm language require the negotiation of free trade accords that fit the model described by Senator Dodd? Because Senator Gramm failed to elaborate on the Senate floor regarding the intent of the language he inserted into TPA, there is no directly relevant legislative history to serve as interpretive guidance. The senator's statements during the debate over the U.S.-Jordan Free Trade Area Implementation Act in September 2001, however, suggest that he would answer the question affirmatively.

In the context of the U.S.-Jordan Free Trade Area Implementation Act, Gramm articulated at length his opposition to the U.S.-Jordan FTA requirement that parties strive to ensure that their laws meet international standards, to improve those standards, and to ensure that they do not waive or derogate from

68. 148 Conc. Rec. S4826 (daily ed. May 23, 2002) (statement of Sen. Dodd). 
domestic labor laws or offer to do so to encourage trade. He perceived these requirements as a threat to U.S. sovereignty, noting:

What is wrong is, for the first time, [the U.S.-Jordan FTA] brings into a trade agreement items that have to do with domestic law. It brings into a free trade agreement provisions that relate to labor law and labor standards... in America. And in the process, we are literally transferring a degree of American sovereignty in labor ... areas to decision-making entities that will be beyond the control of the United States. This is a very serious matter. ${ }^{69}$

Senator Gramm also repeatedly clarified that his vote for the U.S.-Jordan FTA "sets no precedent in terms of our willingness to cede sovereignty over America's right to set its own ... labor laws ... without being penalized in world trade because some international decisionmaking body decides, in doing so, we benefited ourselves in terms of trade." ${ }^{70}$

To determine whether TPA's Gramm language accomplishes the ends for which the senator may have hoped, however, it must be assessed according to established rules of statutory interpretation. These rules indicate that:

Where the meaning of a statute is in doubt, reference to legislation in other states and jurisdictions which pertains to the same subject matter, persons, things, or relations, may be a helpful source of interpretive guidance. One need only show through the similarity of language that the act being construed was copied from another state or states. ${ }^{71}$

Thus, insofar as the U.S.-Jordan FTA, which became U.S. law through the signing of the U.S.-Jordan Free Trade Area Implementation Act, contains language similar to TPA, the agreement is relevant to the interpretation of TPA provisions, including the Gramm language. ${ }^{72}$

69. 147 Conc. Rec. S9685 (daily ed. Sept. 24, 2001) (statement of Sen. Gramm).

70. 147 Cong. Rec. S9687 (daily ed. Sept. 24, 2001) (statement of Sen. Gramm).

71. 2A Singer, supra note 67, at 307-09.

72. As discussed above, TPA incorporates into its overall and principal negotiating objectives many, though not all, of the workers' rights provisions of the U.S.-Jordan FTA. 19 U.S.C. $\S 3803$ (Supp. II 2002). 
Like the Gramm language, the U.S.-Jordan FTA recognizes a country's "right to establish domestic labor standards."73 Going even further, the U.S.Jordan FTA also explicitly recognizes a country's right "to adopt or modify accordingly its labor laws and regulations. ${ }^{174}$

It is axiomatic that inherent in every right is the freedom to enjoy it without suffering negative consequences. If it were otherwise, the right would be rendered meaningless. Thus, when the U.S.-Jordan FTA recognizes a country's right to set its own labor laws, it implicitly bars retaliation based on the exercise of that right. When the Gramm language adds in TPA, explicitly, that "no retaliation may be authorized based on the exercise of ... the right to establish domestic labor standards," it is, therefore, once again simply redundant, articulating the truism that retaliation cannot be based on the exercise of an established right.

In addition to recognizing a country's right to establish, adopt, and modify its labor laws, however, the U.S.-Jordan FTA also requires a country to strive to ensure that those domestic labor laws uphold international standards, to improve them, and not to weaken them or offer to do so to attract trade. This requirement is enforceable through the same dispute settlement procedures as all other accord provisions and its violation subject to equal remedies. On its face, this requirement may appear at odds with a country's sovereign right to legislate, also recognized in the U.S.-Jordan FTA.

Following basic rules of statutory interpretation that seek to avoid internal contradictions, ${ }^{75}$ however, the rights reaffirmed by the U.S.-Jordan FTA must be compatible with the requirements established. How is this possible? The right to legislate is a procedural right devoid of substantive content. Therefore, it is not inconsistent for the U.S.-Jordan FTA to recognize a country's right to establish domestic labor laws while placing substantive restrictions on the exercise of that right, requiring that a country either strive to meet certain workers' rights goals or face negative consequences. Such retaliation, however, is not based on the exercise of the procedural right to legislate. Instead, it is based on violation of the substantive workers' rights framework within which that right must be exercised.

Similarly, free trade accords negotiated under TPA could also contain the same enforceable substantive requirements for countries' domestic labor legisla-

73. U.S.-Jordan FTA, supra note 38, art. 6(3), 41 I.L.M. at 70.

74. Id.

75. See 2A Singer, supra note 67, at 500. 
tion as the U.S.-Jordan FTA without running afoul of the Gramm language. If Senator Gramm had wished to prevent free trade accords negotiated under TPA from containing the third component of the Jordan standard on workers' rights, the language he added should have barred any enforceable substantive parameters on the exercise of the procedural right to legislate, explicitly banning retaliation based on a country's failure to strive to ensure that it does not weaken or reduce domestic labor laws or offer to do so as an encouragement for trade, to ensure that its domestic labor laws meet international standards, and to improve them in that light.

\section{Free Trade Accords under TPA}

No accord completed under TPA, however, meets the Jordan standard on workers' rights. ${ }^{76}$ Instead, although these recently negotiated agreements include a number of labor rights provisions, only one is enforceable and subject to the accords' dispute settlement mechanisms and remedies if violated: the requirement that countries effectively apply domestic labor laws in matters affecting trade between them. ${ }^{77}$ While the accords incorporate, almost verbatim, the U.S.-Jordan FTA requirements that countries strive to ensure that their laws meet international standards, that they improve them, and that they not waive or derogate from them or offer to do so to attract trade, none of these provisions is enforceable. Their violation cannot give rise to dispute settlement or punitive consequences for the violators.

Thus, in negotiating free trade agreements since 2002, U.S. negotiators have generally interpreted TPA's provisions on workers' rights as a ceiling, not a

76. See United States-Chile Free Trade Agreement, U.S.-Chile, June 6, 2003, Hein's No. KAV 6375; United States-Singapore Free Trade Agreement, U.S.-Sing., May 6, 2003, Hein's No. KAV 6376; United States-Morocco Free Trade Agreement, U.S.-Morocco, June 15, 2004, Hein's No. KAV 7206; United States-Australia Free Trade Agreement, U.S.-Aus., May 18, 2004, Hein's No. KAV 6422; Agreement Between the Government of the United States of America and the Government of the Kingdom of Bahrain on the Establishment of a Free Trade Area, U.S.-Bahr., Sept. 14, 2004, Hein's No. KAV 6866; United States-The Dominican Republic-Central America Free Trade Agreement, U.S.-Dom. Rep.-Cent. Am., Aug. 5, 2004, Hein's No. KAV 7157.

77. The accords define the "labor laws" that countries must effectively apply as those statutes and regulations directly related to the same five workers' rights identified by TPA as "core labor standards." See supra note 34 . As a result, those statutes and regulations governing employment and occupation discrimination are not among the labor laws that countries must effectively enforce under the agreements. 
floor. ${ }^{78}$ TPA requires only that the principal negotiating objectives on labor, not the overall negotiating objectives or the specifically articulated priorities, give rise to enforceable accord provisions, and this is the guideline that has been largely followed. ${ }^{79}$

\section{Conclusion}

Senator Baucus told the Democratic Leadership Council, "[T]here will always be those that say the fast track bill doesn't do enough on labor.... To them I say that this bill is an enormous step forward. It is far stronger on these issues than any previous grant of fast track." ${ }^{80}$ TPA, however, is not a step forward. It is a step backward from the Trade Act of 1974, which instructed U.S. trade negotiators to "take such action as may be necessary" to ensure that the global trading system, as governed by the GATT, included an enforceable requirement backed up through public petition and confrontation procedures and that countries adhere to "international fair labor standards." "11 Though TPA does not categorically ban the negotiation of trade accords containing such an enforceable requirement, it also does not instruct U.S. negotiators to pursue that goal. Since TPA passage in 2002, all free trade accords negotiated between the United States and its trading partners have fallen far short of this standard.

78. One notable exception, however, is that these accords include the requirements that countries strive to ensure that their laws meet international standards, that they improve them in that light, and that they not offer to weaken their labor laws as an encouragement for trade, though TPA omits any such language from its negotiating objectives.

79. U.S. trade negotiators have, however, failed even to follow this guideline with respect to TPA's principal negotiating objective to "strengthen the capacity of United States trading partners to promote respect for core labor standards." Recently negotiated free trade agreements include capacity building mechanisms for this purpose, yet none include an enforceable provision establishing that failure to fulfill this responsibility violates the accord and can be subject to dispute settlement and appropriate remedies.

80. Senator Max Baucus, Statement to the Democrat Leadership Council (Feb. 12, 2001).

81. Trade Act of 1974, Pub. L. No. 93-618, § 121(a), 88 Stat. 1978, 1986 (1975). 
